\title{
Interspecific Protoplast Fusion between Streptococcus cremoris and Streptococcus lactis
}

\author{
Takashi Oкамото, Yasuhito Fujita and Ryozaburo IRIE \\ National Institute of Animal Industry, P.O. Box 5 , \\ Tuskuba Norin-Danchi, Ibaraki 305, Japan
}

Received September 27, 1984

\begin{abstract}
Interspecific recombinants have been produced between Streptococcus cremoris $\mathrm{H}-61$ and $S$. lactis $\mathrm{J}-1$ by polyethylene glycol-induced protoplast fusion. All of the fusants obtained showed mixed physiological properties of the two parents, and possessed plasmids derived from both parents at random. Physiological properties of primary colonies were stably maintained among the progenies after the single-colony isolation procedure. Similarly, in most of the fusants the plasmid profiles of the primary colonies were stably maintained, but one lost 2 out of the 7 plasmid bands. However, there was no indication that plasmids from either one of the parents were preferentially lost. These results showed that interspecific genetic transfer occurred on chromosomal and plasmid DNA on the protoplast fusion and that the fusants obtained were not heterokaryons, but true recombinants.
\end{abstract}

The economic value of lactic streptococci, which include Streptococcus cremoris, S. lactis and $S$. lactis subsp. diacetylactis, is well recognized, and efforts to improve strains of this genus have been made by using random mutagenesis. With the progress of molecular genetics in lactic streptococci, useful genetic transfer systems, such as transformation, ${ }^{1)}$ transduction $^{2)}$ and conjugation, ${ }^{3,4)}$ have been demonstrated. Whilst these developments are of potential value, a fourth method of a gene transfer system, protoplast fusion, appears to have broad utility for effective genetic recombination. The fusion process has been shown to generate large numbers of random recombinants. Furthermore, because the fusion is neither strain- nor species-specific, this method of gene transfer may be advantageous for strain improvement.

Techniques for the production and regeneration of protoplasts in lactic streptococci have been established, ${ }^{5)}$ and recently intraspecific genetic recombination by protoplast fusion was reported. ${ }^{6,7)}$ In this communication, we report the formation of interspecific hybrids between $S$. cremoris and $S$. lactis by polyethylene glycol-induced fusion of their proto- plasts.

\section{MATERIALS AND METHODS}

Bacterial strains. S. cremoris $\mathrm{H}-61$ and $S$. lactis $\mathbf{J}$ were maintained in our stock culture collection. $S$. lactis $\mathrm{J}-1$ was a spontaneous $\mathrm{Lac}^{-}$mutant derived from $S$. lactis $\mathbf{J}$ and was resistant to $1 \mathrm{mg} / \mathrm{ml}$ streptomycin. These strains were maintained by biweekly transfer in basal-glucose or basallactose broth. ${ }^{8)}$

Protoplast fusion. Protoplasts of the strains, S. cremoris H-61 and $S$. lactis J-1, were prepared by treatment with lysozyme and $\alpha$-amylase, and treated with polyethylene glycol (PEG) 6000 as described previously. ${ }^{7)}$ The PEGtreated were diluted by adding four $\mathrm{ml}$ of Tris- $\mathrm{HCl}-$ magnesium-sucrose buffer, ${ }^{7)}$ and then $0.1 \mathrm{ml}$ aliquots were plated on regeneration medium..$^{7)}$ After 5 days' incubation at $30^{\circ} \mathrm{C}$, the plates were replicated with sterile velvets onto selective medium ${ }^{7)}$ containing $500 \mu \mathrm{g}$ steptomycin per $\mathrm{ml}$. The plates were incubated at $30^{\circ} \mathrm{C}$ for 2 days and $\mathrm{Lac}^{+}$ $\mathrm{Stm}^{\mathrm{r}}$ primary colonies were isolated. Then the physilogical properties and plasmid profiles of the colonies were checked.

Physiological characteristics. Growth in basal-glucose broth in the presence of $4 \%$ sodium chloride or at $40^{\circ} \mathrm{C}$ was observed as visible turbidity. Arginine hydrolysis was investigated with Nessler's reagent to detect ammonia by the method of Niven et al. ${ }^{9)}$ Test organisms were inoculated into basal broth containing $0.04 \%$ bromocresol purple (BCP) and maltose as a sole carbon source, and 
then incubated at $30^{\circ} \mathrm{C}$ for $24 \mathrm{hr}$. Acid production from maltose was confirmed from the color of the indicator dye.

Plasmid analysis. Plasmid DNA from the strains of lactic streptococci was prepared after lysis by the method of LeBlanc and Lee. ${ }^{10)} S$. faecalis plasmids pAM $\alpha, \mathrm{pAM} \beta$ and $\mathrm{pAM} \gamma$, and Bacillus subtilis pTP5 were isolated for use as mobility references by the methods of LeBlanc and Lee $^{10)}$ and Gryczan et al., ${ }^{11)}$ respectively. Agarose gel electrophoresis was carried out as described by Meyers et al. ${ }^{12)}$ in a horizontal gel at $30 \mathrm{~V}$ for $16 \mathrm{hr} .20 \mu \mathrm{l}$ plasmid DNA and $10 \mu \mathrm{l}$ tracking dye per sample were electrophoresed in a 0.5 .or $0.7 \%$ agarose gel. The gels were stained for $60 \mathrm{~min}$ in $0.5 \mu \mathrm{g}$ of ethidium bromide per $\mathrm{ml}$ and then photographed under a long-wave ultraviolet light.

Stability of fusants. To examine the stability of some phenotypes in the fusants obtained, the organisms were streaked on BCP-lactose indicator medium. ${ }^{13)}$ A typical $\mathrm{Lac}^{+}$colony was transferred to a tube of basal-lactose broth and grown at a $30^{\circ} \mathrm{C}$ for $16 \mathrm{hr}$. Then the culture was streaked over the surface of indicator medium for the isolation of $\mathrm{Lac}^{+}$colonies. All plates were incubated at $30^{\circ} \mathrm{C}$ for 2 days. The procedure was repeated three times. 9 to 10 typical $\mathrm{Lac}^{+}$colonies were isolated from each fusant, and then their properties were checked.

Physiological properties, $4 \%$ sodium chloride tolerance and ammonia from arginine, were examined. To examine the stability of lactose metabolism, a typical $\mathrm{Lac}^{+}$clone was chosen from 9 or 10 isolates and grown under specified experimental conditions. The frequency of spontaneous $\mathrm{Lac}^{-}$reversion from $\mathrm{Lac}^{+}$was determined under the cultural conditions of growth in lactic broth. ${ }^{14)}$ The test organisms were grown in lactic broth at $30^{\circ} \mathrm{C}$ in the presence of $10 \mu \mathrm{g} / \mathrm{ml}$ acridine orange or at elevated temperature $\left(38^{\circ} \mathrm{C}\right)$. The cultures were diluted with saline and plated over the surface of indicator medium. After $48 \mathrm{hr}$ incubation at $30^{\circ} \mathrm{C}$, colonies were counted and the frequency of segregation from $\mathrm{Lac}^{+}$to $\mathrm{Lac}^{-}$was determined.

Plasmid profiles of all the isolates were determined electrophoretically by the method described above, and their stability was checked.
RESULTS

Formation and characterization of interspecific fusants

After PEG treatment of a mixture of protoplasts of $S$. lactis $\mathrm{J}-1$ and $S$. cremoris $\mathrm{H}-61$, $\mathrm{Lac}^{+} \mathrm{Stm}^{\mathrm{r}}$ clones were obtained at the frequency of about $10^{-5}$ per regenerated $S$. lactis $\mathrm{J}-1$ protoplast. This value was lower than that reported for intraspecific fusion in S. lactis. ${ }^{7}$ ) Five primary $\mathrm{Lac}^{+} \mathrm{Stm}^{\mathrm{r}}$ colonies, A-1, A-2, A$3, \mathrm{~A}-4$ and A-5, were isolated and their characteristics were investigated.

Although there is no remarkable difference between $S$. cremoris and $S$. lactis with respect to morphology, $S$. lactis mostly forms pairs or short chains whereas $S$. cremoris forms long chains. Microscopic observation of the interspecific hybrids revealed that A-1, A-3 and A-4 form pairs or short chains, and A-2 and A5 form long chains, suggesting that the former are the $S$. lactis type and the latter the $S$. cremoris type in morphology (Table I).

From a taxonomical point of view, S. lactis produces ammonia from arginine and grows at $40^{\circ} \mathrm{C}$ or in broth containing $4 \%$ sodium chloride or with maltose as a sole cabon source, but $S$. cremoris gives negative reactions in these physiological tests. As shown in Table I, all of the fusants could not grow at $40^{\circ} \mathrm{C}$ or in broth containing maltose. Therefore, these properties were the same as those of $S$. cremoris. On the other hand, the property of ammonia production from arginine was the same as that of $S$. lactis. A-1, A-3 and A-4

Table I. Physiological Properties of $S$. cremoris H-61, S. lactis J-1 and Their Fusants

\begin{tabular}{|c|c|c|c|c|c|c|c|}
\hline \multirow{2}{*}{ Properties } & \multicolumn{7}{|c|}{ Strain } \\
\hline & $\mathrm{H}-61$ & A-1 & A-2 & A-3 & A-4 & A-5 & $\mathrm{J}-1$ \\
\hline Maltose fermentation & - & - & - & - & - & - & + \\
\hline Arginine hydrolysis & - & + & + & + & + & + & + \\
\hline $\begin{array}{l}\text { Growth in the presence } \\
\text { of } 4 \% \mathrm{NaCl}\end{array}$ & - & + & - & + & + & - & + \\
\hline Growth at $40^{\circ} \mathrm{C}$ & - & - & - & - & - & - & + \\
\hline Morphology* & $\mathrm{C}$ & $\mathrm{L}$ & $\mathrm{C}$ & $\mathrm{L}$ & $\mathrm{L}$ & $\mathrm{C}$ & $\mathrm{L}$ \\
\hline
\end{tabular}

* C, S. cremoris type; L, S. lactis type. 


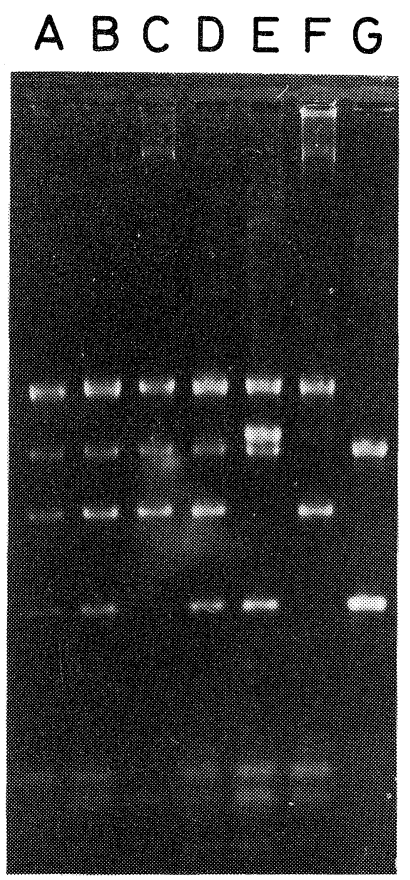

FIG. 1. Agarose Gel Electrophoresis of Plasmid DNA from $S$. cremoris H-61 (well F), S. lactis (well G) and Their Fusants.

Well $\mathrm{F}$ shows (top to bottom) the banding of plasmids having molecular weights of 11.4, 7.7, 2.6, 2.1 and 1.8 Mdal. Well $\mathrm{G}$ shows the banding at the 9.5 and $5.0 \mathrm{Mdal}$ positions. Wells A, B, C, D and E represent A-5, A-4, A-3, A-2 and A-1, respectively.

could grow in broth containing $4 \%$ sodium chloride, but A-2 and A-5 could not. These results showed that the properties of the five clones obtained were distinctly different from those of the parental strains and that they were interspecific recombinants between $S$. cremoris H-61 and S. lactis J-1.

Group N streptococci possess a diversity of plasmid molecules, some of which encode industrially important traits, such as lactose metabolism, ${ }^{15 \sim 17)}$ and protease ${ }^{15)}$ and citrate utilization, ${ }^{18)}$ and the plasmid profile is inherent to a specified strain. The plasmid profiles on agarose gel electrophoresis of $S$. cremoris $\mathrm{H}-61$ and $S$. lactis $\mathrm{J}-1$ are shown in Fig. 1. S. cremoris $\mathrm{H}-61$ possessed 5 plasmid species of $11.4,7.7,2.6,2.1$ and 1.8 megadaltons (Mdal), and $S$. lactis $\mathrm{J}-1$ possessed 9.5 and 5.0 Mdal plasmids. It was evident that
Table II. Stability of Physiological Properties of Fusants

\begin{tabular}{|c|c|c|c|c|}
\hline \multirow{3}{*}{ Strains } & \multicolumn{4}{|c|}{ Physiological properties } \\
\hline & \multicolumn{2}{|c|}{ Arginine hydrolysis } & \multicolumn{2}{|c|}{$4 \% \mathrm{NaCl}$ tolerance } \\
\hline & Primary* & Isolates** & Primary* & Isolates** \\
\hline $\mathrm{H}-61$ & - & & - & \\
\hline A-1 & + & $10 / 10$ & + & $10 / 10$ \\
\hline A-2 & + & $10 / 10$ & $\cdot-$ & $10 / 10$ \\
\hline A-3 & + & $9 / 9$ & + & $9 / 9$ \\
\hline A-4 & + & $10 / 10$ & + & $10 / 10$ \\
\hline A-5 & + & $9 / 9$ & - & $9 / 9$ \\
\hline $\mathrm{J}-1$ & + & & + & \\
\hline
\end{tabular}

* Primary colony obtained after protoplast fusion.

** Number of isolates which exhibit the same properties as the primary colony/number of isolates obtained after the single-colony isolation procedure.

the plasmid profiles of the two parental strains were quite distinct. All of the fusants possessed 11.4 and $9.5 \mathrm{Mdal}$ plasmids. The remaining plasmids, $1.8,2.1,2.6,5.0$ and 7.7 Mdal, were present in varying permutations across the five strains. These results showed that the fusants possessed plasmids of the two parents at random, and the tendency that the profiles were inclined toward either one of the parents was not observed. In addition to the plasmids mentioned above, strain A-1 possessed a $10.0 \mathrm{Mdal}$ plasmid. A band corresponding to a similar molecular size was also detected in $S$. cremoris $\mathrm{H}-61$, but it was too faint to be identified as a distinct plasmid. At present, therefore, we are not certain whether the $10 \mathrm{Mdal}$ plasmid of A-1 originates from H-61 or not.

\section{Genetic stability of fusants}

To determine whether the interspacific hybrids were heterokaryons, single-colony isolation was performed for each of the hybrids three times, and then the physiological properties were checked. As shown in Table II, all of the isolates exhibited the same phenotypes as those of the primary colonies obtained after protoplast fusion.

Since many industrially important functions are encoded on plasmid DNA in lactic strep- 

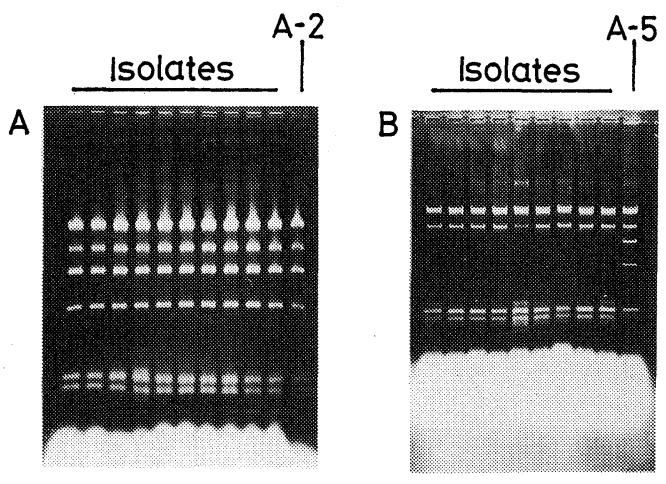

FIG. 2. Agarose Gel Electrophoresis of Plasmid DNA from Primary Colonies and Isolates of A-2 (A) and A-5 (B).

The bright diffuse bands at the bottom of the gels represent residual RNA. Electrophoresis in experiment (B) was conducted at $100 \mathrm{~V}$ for $4 \mathrm{hr}$.

tococci, it is important to elucidate whether the plasmids in a primary colony are stably maintained among the progeny. Examples of the plasmid pattern on agarose gel electrophoresis are shown in Fig. 2. It is evident that all plasmids in strain A-2, which contained all of the plasmids of both parents, are maintained among the progeny after the three single-colony isolation procedure. Similar results were obtained for strains A-1, A-3 and A4 (data not shown). On the other hand, as to strain A-5, all of the isolates lost the $7.7 \mathrm{Mdal}$ and 5.0 Mdal plasmids (Fig. 2B). This revealed that in some cases plasmid loss occurred among the progeny. However, it is likely that this loss occurred nonselectively and at random, because the $7.7 \mathrm{Mdal}$ plasmid was derived from $S$. cremoris $\mathrm{H}-61$ and the $5.0 \mathrm{Mdal}$ plasmid from $S$. lactis $\mathrm{J}-1$.

It is well known that the ability to ferment lactose is unstable and associated with plasmid DNA in many strains of group $\mathrm{N}$ streptococci. ${ }^{15 \sim 17)}$ Considering the strain improvement of these organisms, it is important to pay attention to the activity and stability of lactose metabolism of the genetic recombinants obtained. The lactose-fermenting ability of $S$. lactis $\mathbf{J}$, which was the $\mathrm{Lac}^{+}$parent of $S$. lactis $\mathrm{J}-1$, was unstable. $12.3 \%$ of the population consisted of $\mathrm{Lac}^{-}$variants after $16 \mathrm{hr}$ growth
Table III. Stability of Lactose Metabolism In The PARENTS AND Their Fusants

\begin{tabular}{lccc}
\hline & \multicolumn{3}{c}{ Frequency of $\mathrm{Lac}^{-}(\%)$} \\
\cline { 2 - 4 } Strains & & \multicolumn{2}{c}{ Curing conditions } \\
\cline { 3 - 4 } & Spontaneous & $\begin{array}{c}\text { Acridine } \\
\text { orange* }\end{array}$ & $\begin{array}{c}\text { Elevated } \\
\text { temperature** }\end{array}$ \\
& & 0 & 0 \\
H-61 & 0 & 63.9 & 14.6 \\
A-1 & 7.6 & 2.8 & 2.4 \\
A-2 & 0 & 2.2 & 5.3 \\
A-3 & 3.3 & 48.8 & 10.2 \\
A-4 & 11.9 & 4.5 & 4.7 \\
A-5 & 0 & 92.6 & 98.2 \\
J & 12.3 & \\
\hline
\end{tabular}

* The cells were incubated in the presence of $10 \mu \mathrm{g}$ of acridine orange per $\mathrm{ml}$.

** The cells were incubated at $38^{\circ} \mathrm{C}$.

in lactic broth. Moreover, when S. lactis J was incubated at $38^{\circ} \mathrm{C}$ or in the presence of acridine orange $(10 \mu \mathrm{g} / \mathrm{ml}), \mathrm{Lac}^{-}$variants appeared at the frequency of $98.2 \%$ and $92.6 \%$, respectively. On the contrary, lactose metabolism of $S$. cremoris was very stable. Curing experiments, using acridine orange and at elevated temperature, did not yield $\mathrm{Lac}^{-}$variants. The stability of the $\mathrm{Lac}^{+}$property in five typical $\mathrm{Lac}^{+}$interspecific fusants is shown in Table III.

\section{DISCUSSION}

Protoplast fusion should play an important role in strain improvement of industrially important organisms, for which the use of the general method of a genetic transfer system is limited. Intraspecific fusion of $S$. lactis has already been reported by several authors. ${ }^{6,7)}$ This paper describes the formation of interspecific recombinants between $S$. cremoris and $S$. lactis by PEG-induced fusion of their protoplasts.

$S$. cremoris and $S$. lactis could be physiologically differentiated from a taxonomical point of view, i.e. maltose fermentation, growth in the presence of $4 \%$ sodium chloride and so on. It has been reported that $S$. lactis subsp. diacetylactis may exhibit variability with re- 
spect to arginine hydrolysis, and that this trait may be an unstable property in some strains. ${ }^{20}$ In $S$. lactis $\mathrm{J}-1$, the arginine-hydrolyzing ability was not encoded on plasmid DNA, because a plasmid free derivative of $S$. lactis J-1 produced ammonia from arginine (data not shown). So physiological traits used as genetic markers may be encoded on chromosomal DNA. Due to the lack of chromosomal maps in lactic streptococci, the number of crossovers required for recombinants, which exhibit specified phenotypes, is not clear. However, as shown in Table I, none of the clones obtained showed only one of parental phenotypes, all showed mixed physiological phenotypes of both parents. This showed that the five clones obtained in these experiments were interspecific recombinants between $S$. cremoris $\mathrm{H}-61$ and $S$. lactis $\mathrm{J}-1$, and that wide range genetic exchange occurred on chromosomal DNA. Furthermore, the results of plasmid analysis by agarose gel electrophoresis showed that strains A-2 and A-4 possessed all of the plasmids of both parents, and similarly A-1, A-3 and A-5 possessed not all but several plasmids derived from both parents; $S$. cremoris H-61 and $S$. lactis $\mathrm{J}-1$ harbor 5 and 2 distinct plasmid species, respectively (Fig. 1). These results also supported the conclusion that the five clones obtained were interspecific fusants.

Lactic streptococci possess a diversity of plasmid molecules and the functions of most of these plasmids are still unknown. However, some genetic evidence has been obtained for specified plasmid linkage to important metabolic traits, such as lactose fermentation ${ }^{15 \sim 17)}$ and citrate utilization. ${ }^{18)}$ Considering that plasmids of both parents simultaneously existed in fusants and that wide range genetic recombination occurred on chromosomal DNA, protoplast fusion should play an important role in strain improvement.

Protoplast fusion was expected to produce di- or multi-nucleated products in a primary state. It 'was reported that with Streptomyces antibioticus marked segregation to the original genetypes was observed in many of the prototrophic colonies derived on fusion. ${ }^{21)}$ In contrast, Schaeffer et al. ${ }^{22)}$ showed that in Bacillus subtilis segregation and recombination occurred at an early step, and all of the colonies which appeared on regeneration medium were haploid recombinants. As for streptococcal fusants obtained in these experiments, the genetic stability as to physiological characteristics after the single-colony isolation procedure is especially noteworthy, suggesting the formation of true recombinants. Besides these chromosomal events, four of the five fusants stably maintained the plasmid profiles of the primary colonies even after single-colony isolation. On the other hand, strain A-5 lost the 7.7 Mdal and 5.0 Mdal plasmids. Since the former is derived from $S$. cremoris $\mathrm{H}-61$ and the latter from $S$. lactis $\mathrm{J}-1$, it is not likely that plasmids of either one of the parents only disappeared. However, considering that in lactic streptococci industrially important functions are encoded on plasmid DNA, the phenomenon of plasmid loss may be an obstacle for strain improvement.

Larsen and $\mathrm{McKay}{ }^{23)}$ reported that lactose metabolism of $S$. cremoris was generally a stable property, and in $S$. cremoris AM2 few $\mathrm{Lac}^{-}$variants could be found even when the cells were treated in a variety of ways known to cause a high frequency of $\mathrm{Lac}^{-}$variants in $S$. lactis. Similar results were obtained in this study. S. cremoris H-61 was treated by using common curing conditions but no $\mathrm{Lac}^{-} \mathrm{mu}-$ tants were obtained. On the contrary, the proportion of $\mathrm{Lac}^{-}$mutants in S. lactis $\mathrm{J}$ was extremely increased by the curing treatment (Table III). From the results of overall physiological characteritics, fusants could be classified into two parental types, that is, A-2 and A-5 were the $S$. cremoris type, and A-1, A-3 and A-4 the $S$. lactis type (Table I). In agreement with these results, the lactose-fermenting ability of strains A-1 and A-4 was as unstable as that of $S$. lactis $\mathrm{J}-1$, especially $\mathrm{Lac}^{-}$mutants increased in the population on treatment with acridine orange (Table III). Although strain A3 seemed to be the $S$. lactis type, its lactose metabolism showed more stable characteristics than that of $S$. lactis $\mathbf{J}$ even under the curing 
conditions. It is likely that the lactosefermenting ability of this fusant was stabilized by the influence of the character of $S$. cremoris H-61.

It has been well documented that lactose metabolism in S. lactis and S. lactis subsp. diacetylactis is mediated by plasmid DNA. ${ }^{15 \sim 17)}$ In contrast, not enough genetic evidence has been obtained to elucidate the stability of lactose metabolism in $S$. cremoris. ${ }^{23)}$ Fujita et al. ${ }^{19)}$ recently isolated $\mathrm{Lac}^{-}$ mutants of $S$. cremoris H-61, which simultaneously lost the 61 and $31 \mathrm{Mdal}$ plasmids. This suggested that the lactose metabolism in $S$. cremoris $\mathrm{H}-61$ was similarly encoded on plasmid DNA as in the case of $S$. lactis, ${ }^{16,17)}$ whereas its stability was distinctly different from in S. lactis. It is necessary to elucidate the mechanisms of stable inheritance of plasmids for strain improvement in lactic streptococci.

\section{REFERENCES}

1) J. K. Kondo and L. L. McKay, Appl. Environ. Microbiol., 43, 1213 (1982).

2) L. L. McKay, B. R. Cords and K. A. Baldwin, J. Bacteriol., 115, 810 (1973).

3) M. J. Gasson and F. L. Davies, J. Bacteriol., 143, 1260 (1980).

4) L. L. McKay, K. A. Baldwin and P. M. Walsh, Appl. Environ. Microbiol., 40, 84 (1980).

5) Y. Fujita, T. Okamoto and R. Irie, Agric. Biol.
Chem., 47, 2103 (1983).

6) M. J. Gasson, FEMS Microbiol. Lett., 9, 99 (1980).

7) T. Okamoto, Y. Fujita and R. Irie, Agric. Biol. Chem., 47, 2675 (1983).

8) T. Okamoto, Y. Fujita and R. Irie, Agric. Biol. Chem., 47, 259 (1983).

9) C. F. Niven, Jr., K. L. Smiley and J. M. Sherman, J. Bacteriol., 43, 651 (1942).

10) D. J. LeBlanc and L. N. Lee, J. Bacteriol., 140, 1112 (1979).

11) T. Gryczan, S. Contente and D. Dubnau, $J$. Bacteriol., 134, 318 (1978).

12) J. A. Meyers, D. Sanchez, L. P. Elwell and S. Falkow, J. Bacteriol., 127, 1529 (1976).

13) L. L. McKay, A. Miller, III, W. E. Sandine and P. R. Elliker, J. Bacteriol., 102, 804 (1970).

14) P. R. Elliker, A. Anderson and G. Hannesson, $J$. Dairy Sci., 39, 1611 (1956).

15) M. J. Gasson, J. Bacteriol., 154, 1 (1983).

16) G. M. Kempler and L. L. McKay, Appl. Environ. Microbiol., 37, 1041 (1979).

17) J. D. Efstathiou and L. L. McKay, Appl. Environ. Microbiol., 32, 38 (1976).

18) G. M. Kempler and L. L. McKay, J. Dairy Sci., 64, 1527 (1981).

19) Y. Fujita, T. Okamoto and R. Irie, Agric. Biol. Chem., 48, 1895 (1984).

20) N. Turner, W. E. Sandine, P. R. Elliker and E. A. Day, J. Dairy Sci., 46, 380 (1963).

21) K. Ochi, M. J. M. Hitchcock and E. Katz, J. Bacteriol., 139, 984 (1979).

22) P. Schaeffer, B. Cami and R. D. Hotchkiss, Proc. Natl. Acad. Sci. U.S.A., 73, 2151 (1976).

23) L. D. Larsen and L. L. McKay, Appl. Environ. Microbiol., 36, 944 (1978). 